\title{
PARTIAL CONFINEMENT OF EXTERIOR REINFORCED CONCRETE COLUMNS
}

\author{
Mohamed Alkersh* and Amr M. Hilal \\ Structural Engineering Department, Faculty of Engineering, Al-Azhar University, Cairo, \\ Egypt. \\ *Corresponding Author E-mail: MohamedAlkersh.14@azhar.edu.eg
}

\begin{abstract}
:
This paper presents a program to examine partial confinement of reinforced concrete columns, as an effective and a practical solution to strengthen exterior columns in existing buildings. The effect of confinement area, number of outer stirrups, reinforcement ratio of the column, partially penetrative dowels and fully penetrative dowels on the behavior of reinforced concrete exterior reinforced concrete columns were studied. Experimental and analytical programs (using ABAQUS software) of two groups were performed. Horizontal displacement and strains were measured at different stages of loading. The load strains curves were plotted. The relation between each variable and the capacity of the column was plotted. The final results show that the partially penetrative dowels are more effective than the fully penetrative dowels. The rare faction in the concrete particles in case of fully penetrative dowels caused reduction in failure load in comparison with the expected failure load.
\end{abstract}

\section{KEYWORDS: Partial Confinement, Exterior Columns, Fully Penetrative Dowels, partially Penetrative Dowels, External Stirrups.}

$$
\text { الإحاطة الجزئية للأعمدة الخرسانية الخارجية }
$$

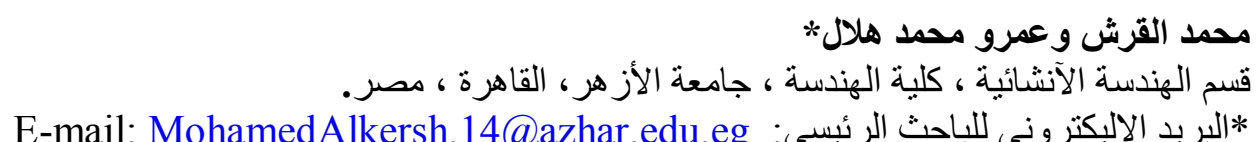

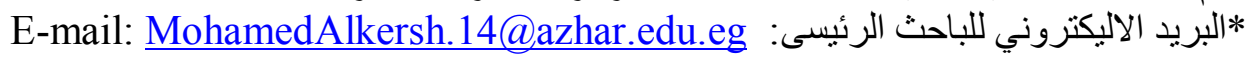

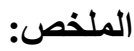
هذا البحث يقدم برنامجا لاختبار الإحاطة الجزئية للأعمدة الخرسانية كحل فعال لتقوية الأعمدة الخارجية في المباني القائية القائمـة.

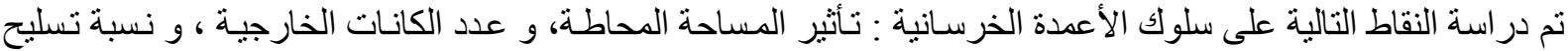

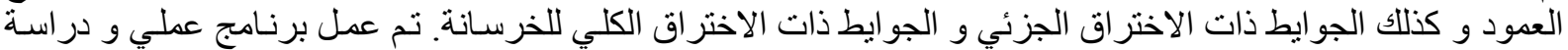

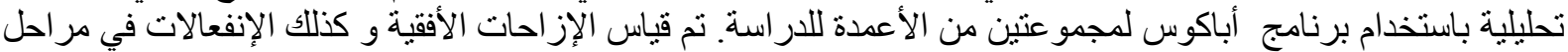

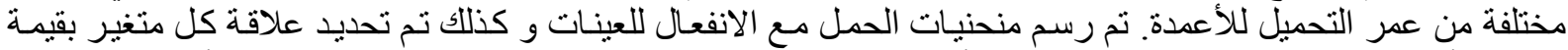

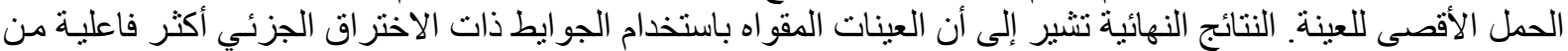

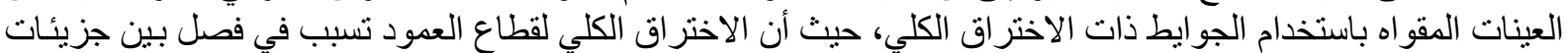
الخرسانة نتج عنه تخفيض في الحمل الحقيقي عن الحمل الحنب المتوقع.

الكلمات المفتاحية : الإحاطة الجزئية ، الأعمدة الخارجية، جوايط ذات اختراق كلي، جوايط ذات اختراق جزئي، 


\section{INTRODUCTION}

Reinforced concrete elements are designed to satisfy safety, serviceability and economy. An increasing number of existing buildings over the world are in need of strengthening or retrofitting due to factors such as additional load, functional change, and/or design errors. Strengthening of reinforced concrete columns is important in the repair and retrofit of concrete structures since the failure of a column has serious consequences for structural stability. The purpose of this study is to propose new techniques to confine reinforced concrete exterior columns.

Exterior columns in existing concrete buildings are hard to be fully confined as exterior walls are adjacent to them. Partial confinement studied in this program should be useful as walls do not need to be demolished while columns are strengthened.

The confined concrete is defined as the concrete, which is restrained in the directions at right angles to the applied stress. R.Park and T.Paulay (1975). In practice, concrete maybe confined by transverse steel (ties), commonly in the form of closely spaced steel spirals or ties.

In case of exterior and corner reinforced concrete columns, it is impossible to create a closed outsider transverse steel (ties), so the suggested technique is to create a confinement area by drilling partially penetrative dowels and fully penetrative dowels with epoxy resin.

The effectively confined area of concrete may even further be reduced due to the arching action of concrete between the transverse ties along the longitudinal axis of the member as shown in Fig. 1. The minimum area of effectively confined concrete is midway between tie levels and will control the strength of the column.

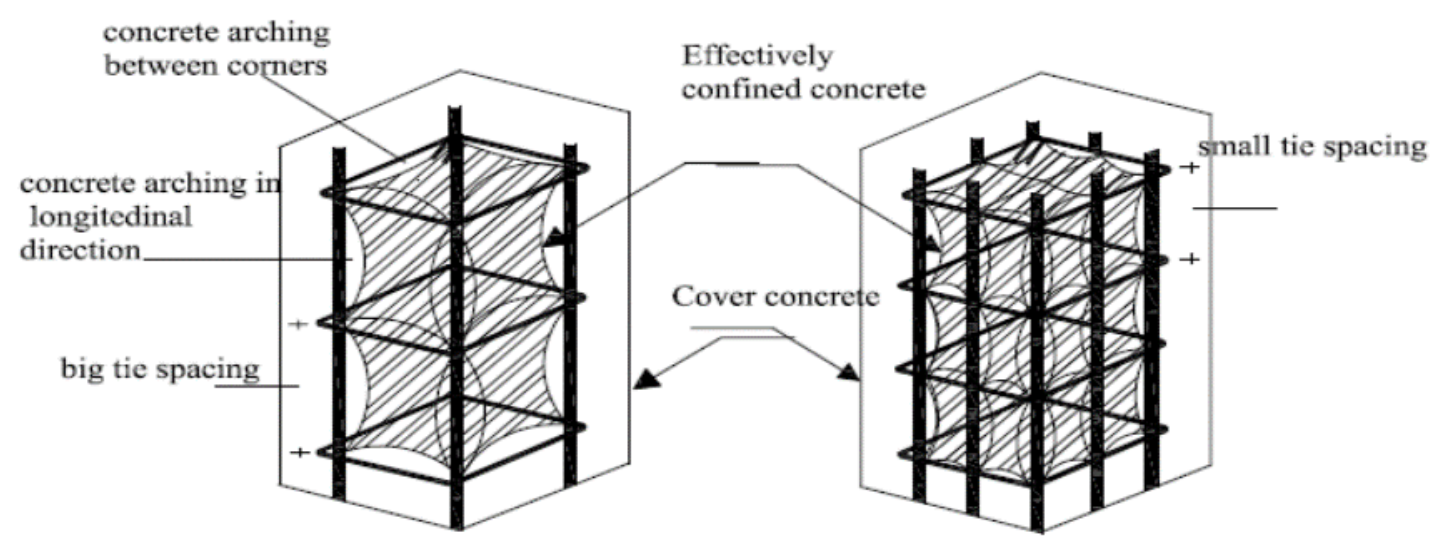

Fig. 1: Three-Dimensional View of Degree of Confinment

As seen in Figure (1), concrete is confined by arching action between transverse steel (ties). Larger tie spacing (S) will result in less confined area and hence lower load-carrying capacity of concrete, whereas smaller tie spacing provides a better confinement, Mander et al (1988). Mander et al. (1988) derived a model for confinement of concrete from experimental values of 17 steel spiral reinforced concrete cylinders with varying ratios of reinforcement. The following relation for strength of confined concrete was proposed:

$f_{c o}^{\prime}=f_{c o}^{\prime}\left(-1.254+2.254 * \sqrt{1+\frac{7.94 * f_{l}^{\prime}}{f_{c o}^{\prime}}}-2 \frac{f_{l}^{\prime}}{f_{c o}^{\prime}}\right)$.

Where:

$\mathrm{f}_{f}^{\prime} \mathrm{co}=$ unconfined concrete compressive strength.

$f_{\mathrm{z}}=$ effective lateral confining pressure $=\mathrm{k}_{\mathrm{e}} \mathrm{x}$ lateral pressure.

$\mathrm{k}_{\mathrm{e}}=$ ratio between effectively confined concrete area and core concrete area.

The longitudinal strain in the confined concrete was proposed as:

$\varepsilon_{\mathrm{cc}}=\varepsilon_{\mathrm{co}}\left[1+5\left(\frac{f_{\mathrm{cc}}^{f}}{f_{t a s}^{f}}-1\right)\right]$

Where:

$\varepsilon_{\mathrm{co}}=$ the longitudinal strain of the confined concrete at failure. 
Larger effective confining pressure would result in higher strength and correspondingly higher strain value. Ductility of the concrete as indicated by the post peak part of the curve will also increase as presented in Fig. 2.

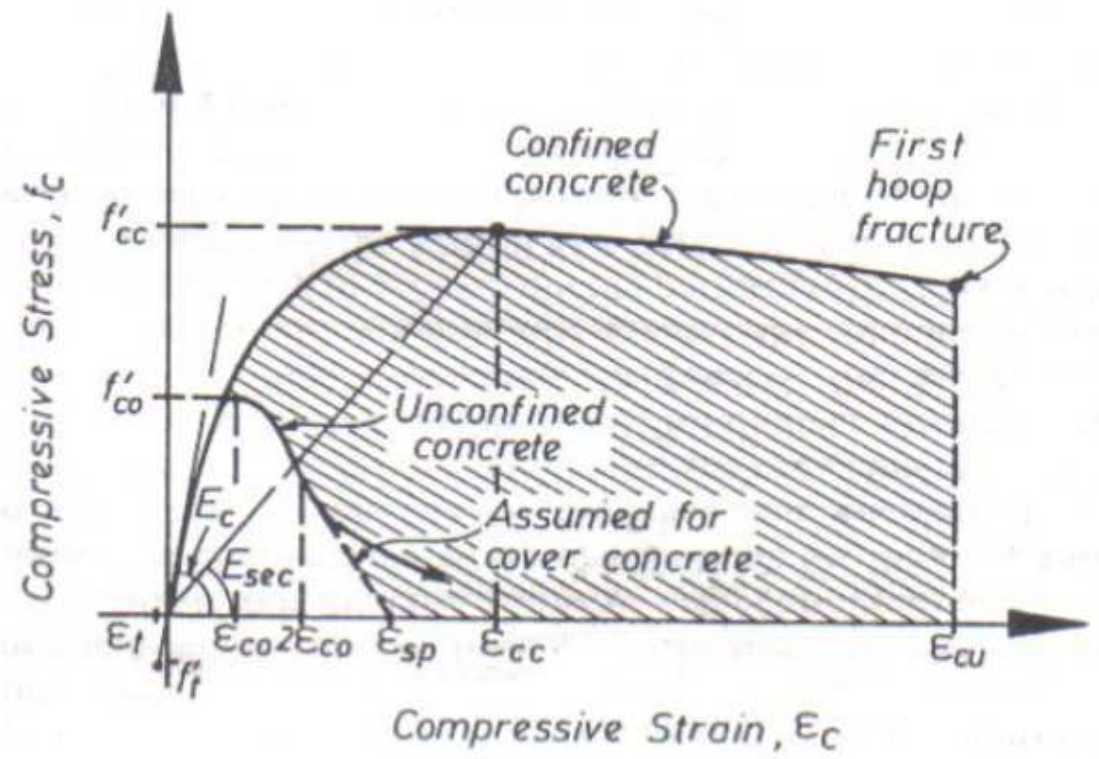

Fig. 2: Stress-Strain Model Proposed by Mander et. al. (1988).

\section{EXPERIMENTAL PROGRAM}

\subsection{Specimen Details}

The experimental program was carried out at the Materials Laboratory, Faculty of Engineering - Al Azhar Universty. The experimental work was carried out on two groups consisting of ten columns. All columns had a cross section of $120 \mathrm{~mm} \times 150 \mathrm{~mm}$ and total length of $1200 \mathrm{~mm}$ (including top and bottom cap to prevent local failure). All specimens in the first group has 4Y8 longitudinal bars and Y6@200 mm stirrups and the first control column had the same reinforcement as shown in Fig. 3. In the second group all specimens had 6Y8 longitudinal bars and Y6@200 mm stirrups and the second control column had the same reinforcement as shown in Fig. 4. The details of strengthening of all specimens are shown in Table 1.

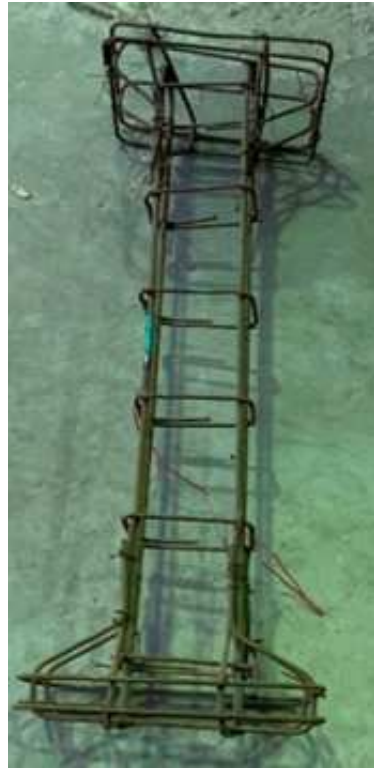

Fig. 3: Reinforcement of Columns in Group (1)

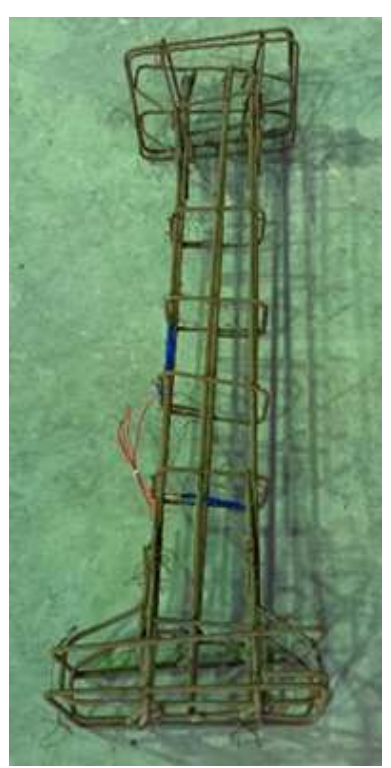

Fig. 4: Reinforcement of Columns in Group (2) 
Table 1: The details of strengthening of all specimens.

\begin{tabular}{|c|c|c|c|}
\hline Group & Specimen \# & Confinement Shape & No. of External Stirrups \\
\hline \multirow{5}{*}{ 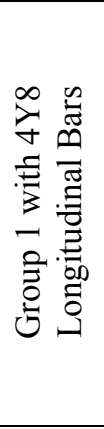 } & $\begin{array}{c}\text { C1-0 } \\
\text { Control Spec. }\end{array}$ & --- & --- \\
\hline & $\mathrm{C} 1-1$ & Partially Penetrative Dowels & $\begin{array}{l}6 \text { steel strips with } 30 \mathrm{~mm} \\
\text { width and } 3 \mathrm{~mm} \text { thickness }\end{array}$ \\
\hline & $\mathrm{C} 1-2$ & Fully Penetrative Dowels & $\begin{array}{l}6 \text { steel strips with } 30 \mathrm{~mm} \\
\text { width and } 3 \mathrm{~mm} \text { thickness }\end{array}$ \\
\hline & $\mathrm{C} 1-3$ & Partially Penetrative Dowels & $\begin{array}{l}8 \text { steel strips with } 30 \mathrm{~mm} \\
\text { width and } 3 \mathrm{~mm} \text { thickness }\end{array}$ \\
\hline & $\mathrm{C} 1-4$ & Fully Penetrative Dowels & $\begin{array}{l}8 \text { steel strips with } 30 \mathrm{~mm} \\
\text { width and } 3 \mathrm{~mm} \text { thickness }\end{array}$ \\
\hline \multirow{5}{*}{ 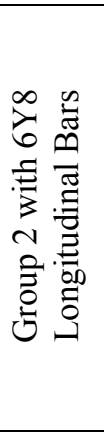 } & $\begin{array}{c}\text { C2-0 } \\
\text { Control Spec. }\end{array}$ & --- & --- \\
\hline & $\mathrm{C} 2-1$ & Partially Penetrative Dowels & $\begin{array}{l}6 \text { steel strips with } 30 \mathrm{~mm} \\
\text { width and } 3 \mathrm{~mm} \text { thickness }\end{array}$ \\
\hline & $\mathrm{C} 2-2$ & Fully Penetrative Dowels & $\begin{array}{l}6 \text { steel strips with } 30 \mathrm{~mm} \\
\text { width and } 3 \mathrm{~mm} \text { thickness }\end{array}$ \\
\hline & $\mathrm{C} 2-3$ & Partially Penetrative Dowels & $\begin{array}{l}8 \text { steel strips with } 30 \mathrm{~mm} \\
\text { width and } 3 \mathrm{~mm} \text { thickness }\end{array}$ \\
\hline & $\mathrm{C} 2-4$ & Fully Penetrative Dowels & $\begin{array}{l}8 \text { steel strips with } 30 \mathrm{~mm} \\
\text { width and } 3 \mathrm{~mm} \text { thickness }\end{array}$ \\
\hline
\end{tabular}

\subsection{Material Properties and Mix Design}

The aimed concrete characteristic strength was $35 \mathrm{MPa}$ so the water / cement ratio used was 0.47 , water quantity was $200 \mathrm{~kg} / \mathrm{m} 3$, cement quantity was $425 \mathrm{~kg} / \mathrm{m} 3$, volume of coarse aggregates was $0.7 \mathrm{~m} 3$ and volume of fine aggregates was $0.35 \mathrm{~m} 3$.Six standard cubes, and $150 \times 150 \times 150 \mathrm{~mm}$, were taken from the concrete at regular intervals during casting of the girders. These control specimens were casted, compacted and cured simultaneously with each tested specimen. They were tested at the time of the beam testing. Results of the cubes testing are presented in Table 2 .

Table 2: Results of Standard Cubes.

\begin{tabular}{c|cccccc}
\hline Cube No. & Cube 1 & Cube 2 & Cube 3 & Cube 4 & Cube 5 & Cube 6 \\
\hline $\begin{array}{c}\text { Strength } \\
(\mathrm{MPa})\end{array}$ & 38.9 & 37.9 & 38.1 & 37.5 & 38.2 & 38.1 \\
\hline
\end{tabular}

One type of steel was used in this program, normal mild steel with yield strength $240 \mathrm{MPa}$. Steel forms coated with oil were used. The reinforcement was placed in its positions in the forms.

Casting took place immediately after mixing. A mechanical vibrator was used in placing the concrete around the reinforcement together with the hand tamping to ensure full compaction. Columns were left in the forms for 48 hours after which the sides of the forms were stripped away. The specimens were submerged in water for the following week. Then they were left in the ordinary atmosphere with average temperature of $24^{\circ} \mathrm{C}$ for at least 28 days before strengthening.

\subsection{Application of Strengthening}

After the passage of 28 days, strengthening was applied according to the following steps:

1. Preparation of concrete surface using a hammer and blower to remove the weak parts on the concrete cover.

2. Washing concrete surface with water.

3. Drilling number of holes in the specimen according to number of outer stirrups. In case of partially penetrative dowels, the dowels were made from two sides as shown in Fig. 5,but in case of fully penetrative dowels, the dowels were made from one side as shown in Fig. 6.

4. In case of fully penetrative dowels some damages occurred in the other side due to drilling. This damage was repaired with a grout. 
5. Two angels $40 * 40 * 4$ were fixed in the two allowable corners with epoxy resin.

6. The outer steel stirps were fixed with thread bar with diameter $8 \mathrm{~mm}$ filled in the previous holes and fixed with a nut and epoxy resin.

7. The outer steel stirps were welded with the angles as shown in Fig. 7.
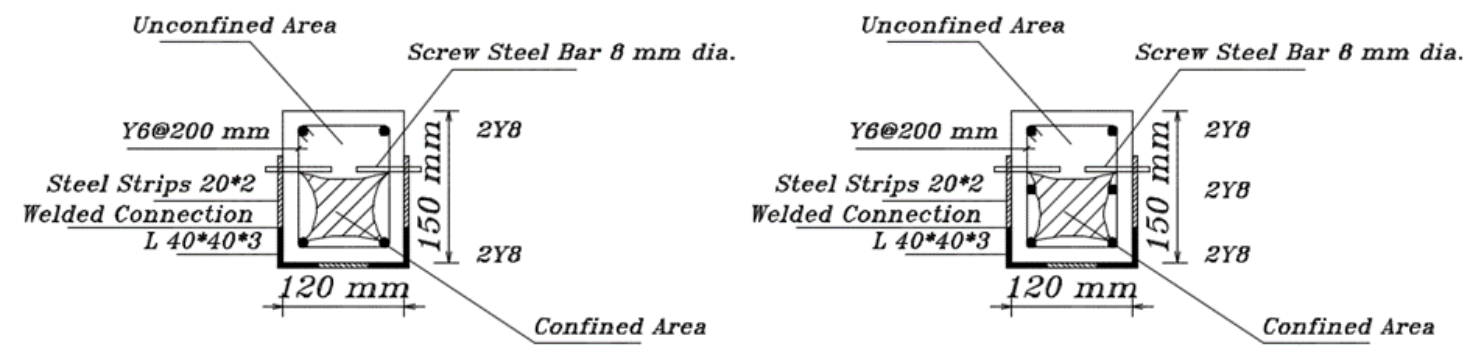

Fig. 5: Partially Penetrative Dowels in Group 1 and Group 2
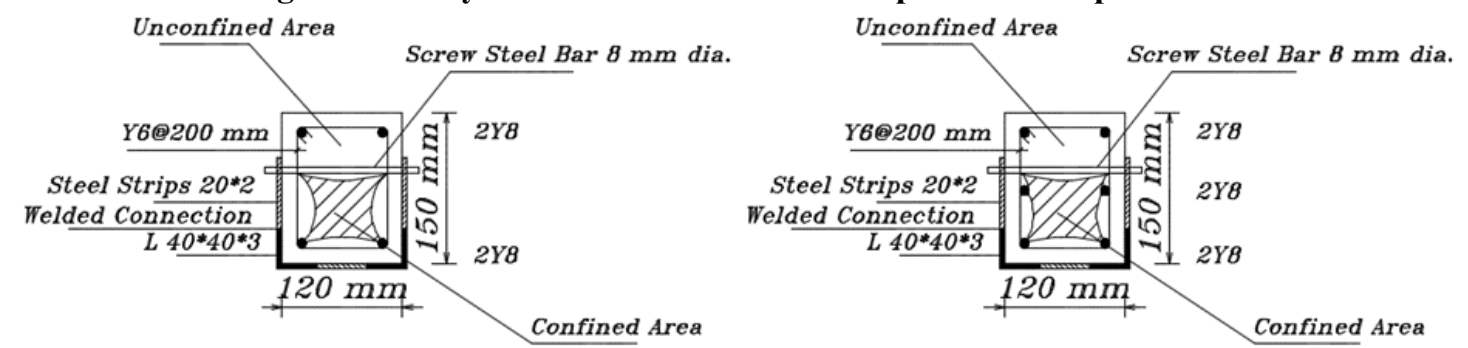

Fig. 6: Fully Penetrative Dowels in Group 1 and Group 2.
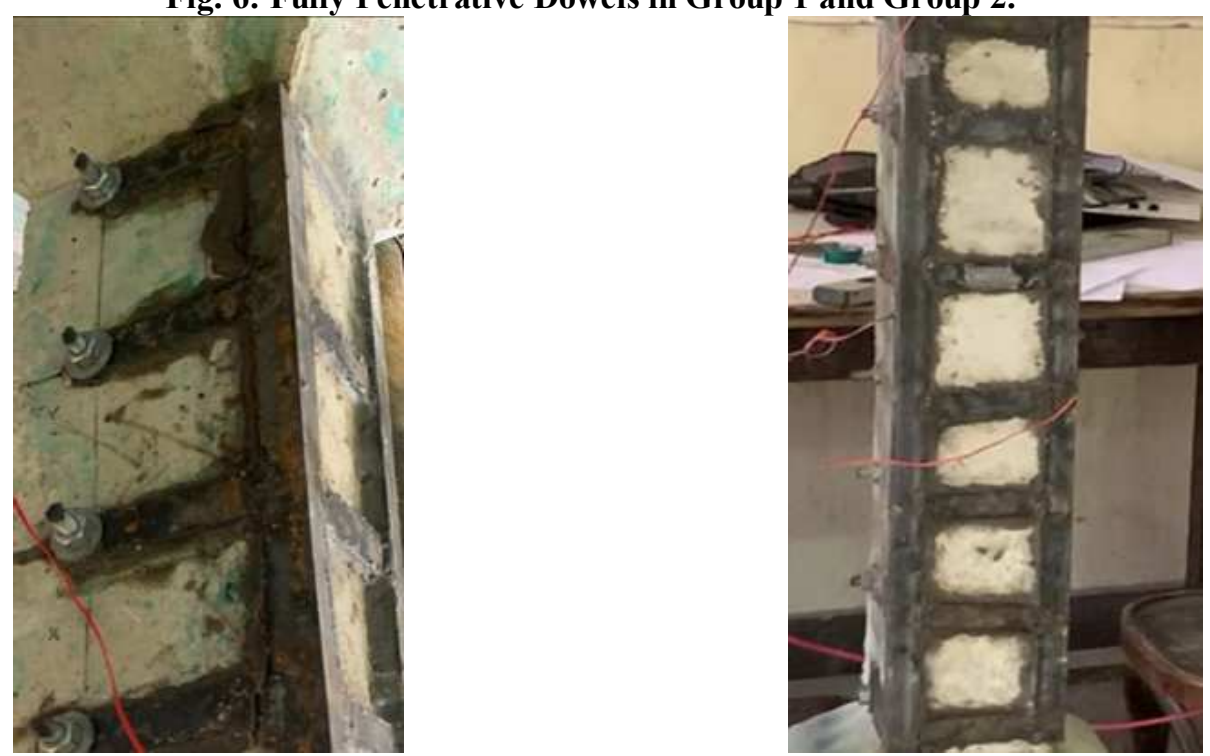

\subsection{Test Setup}

Fig. 7: Welded Connections between Angels and Steel Stirps.

The structural-testing machine in the Reinforced Concrete Laboratory at the Civil Engineering Department of Al-Azhar University was used to test. Horizontal displacement at mid-point of columns was measured using LVDT, while strains of inner longitudinal reinforcement and strains of external stirrups were also observed. The vertical loads were measured at different stages of loading. The test setup is shown in Fig. 8.

\section{RESULTS AND DISCUSSION}

\subsection{Failure Loads}

The failure loads of the tested columns were compared with estimated failure loads due to the assumption of estimated failure load of unconfined area and failure load of confined area according to Mander et al .(191^) . 


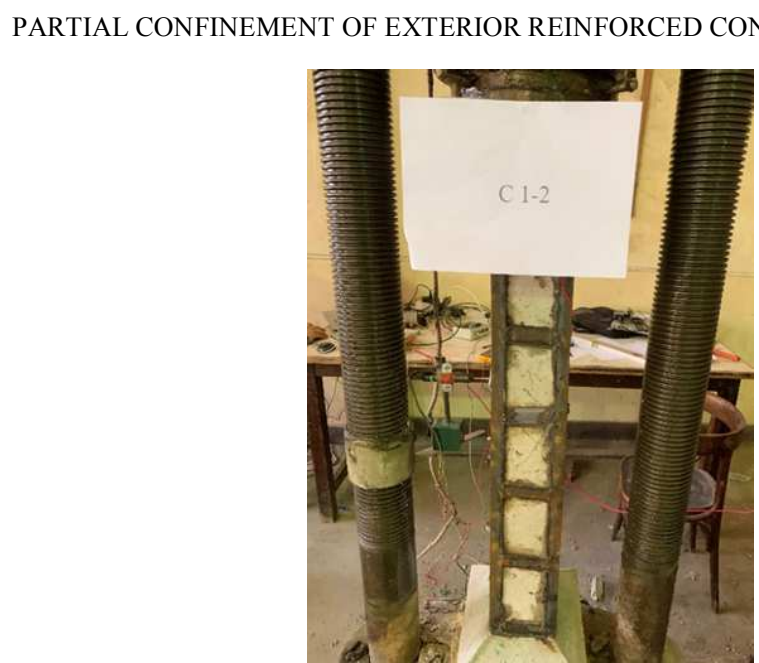

Fig. 8: Test Setup .

For Group 1 the experimental failure loads were bigger than the estimated failure loads with average ratio 3\% and the experimental failure loads are shown in Fig. (9).

For Group 2 the experimental failure loads are bigger than the estimated failure loads with average ratio 5\% and the experimental failure loads are shown in Fig. (10).

The failure mode in all specimens occurs in the unconfined zone as shown in Fig. (11)

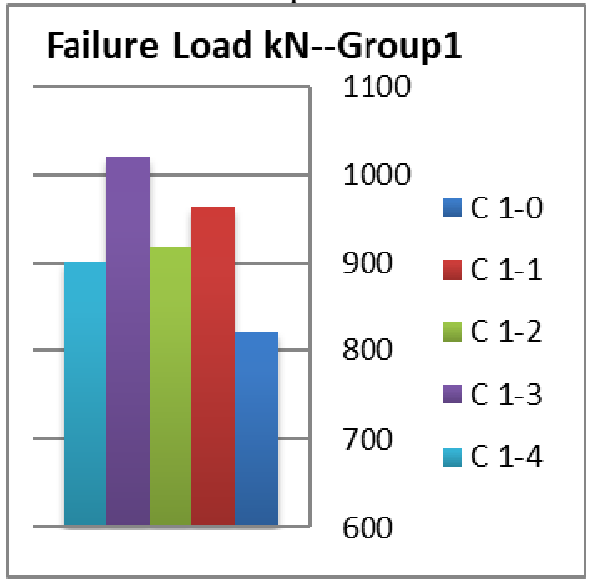

Fig. 9: Failure Loads for Group (1)

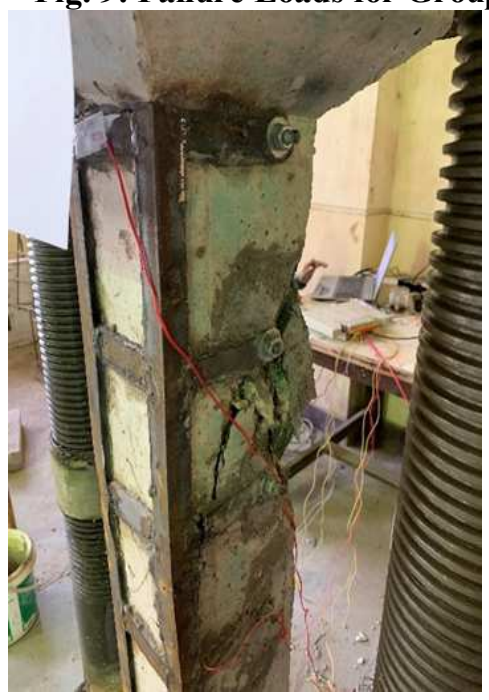

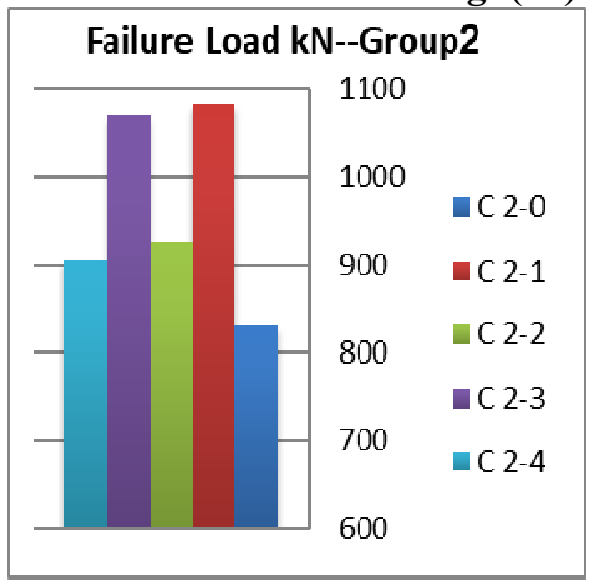

Fig. 10: Failure Loads for Group (2)

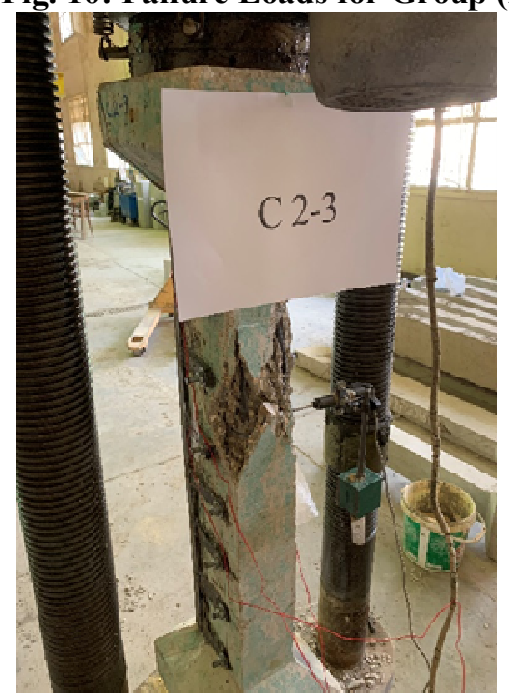



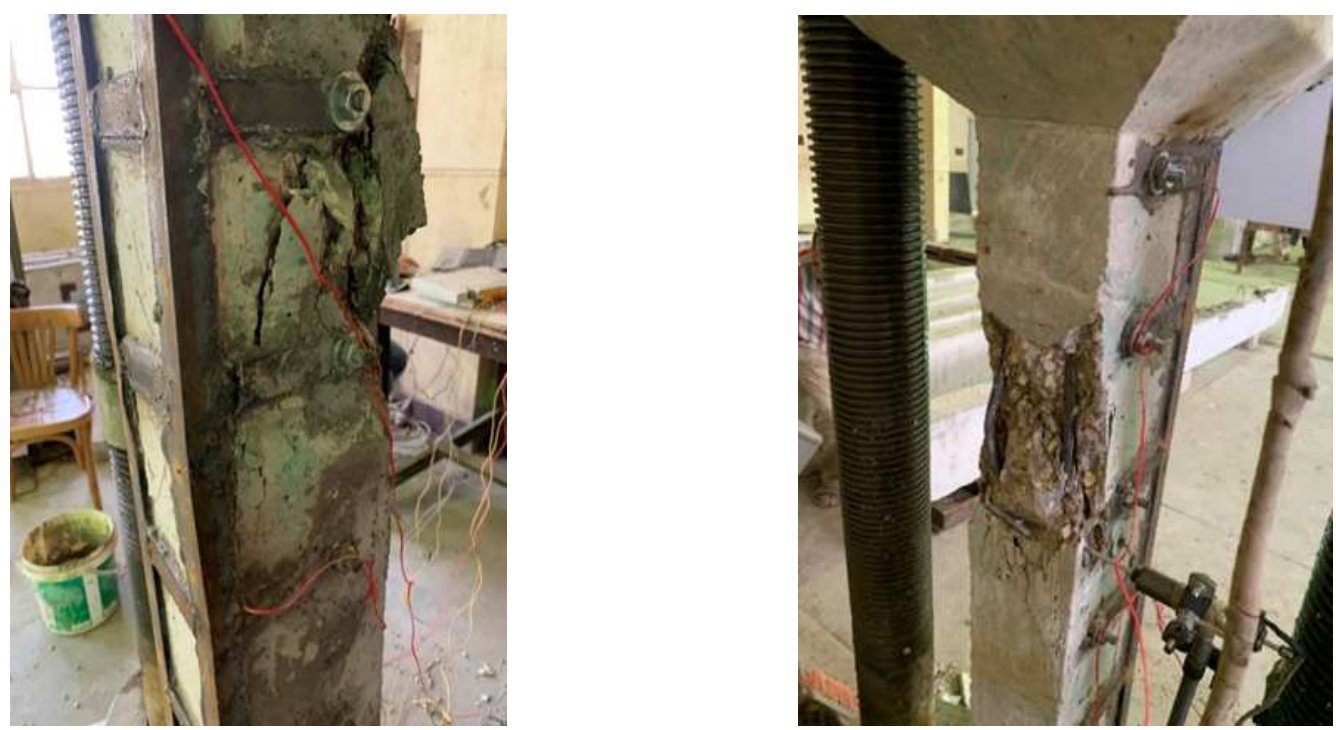

\subsection{Steel Strains}

Fig. 11: Failure Modes of Different Specimen

The longitudinal steel strains and outer stirrups strain were obtained from the electrical strain gauges. Figures 12 and 13 show the load and longitudinal steel strain curves through the load history for group 1 and group 2 respectively. Figures 14 and 15 show the load and outer stirrups strain curves through the load history for group 1 and group2 respectively.

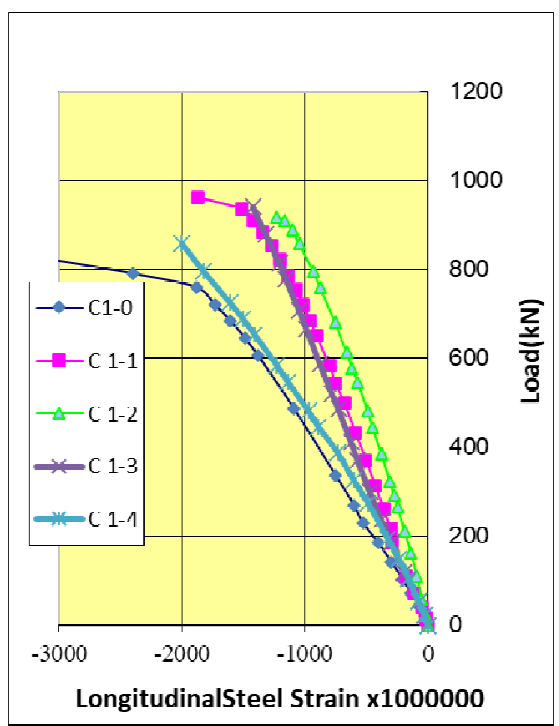

Fig. 12: Load-Steel Strain Curves for Group (1)

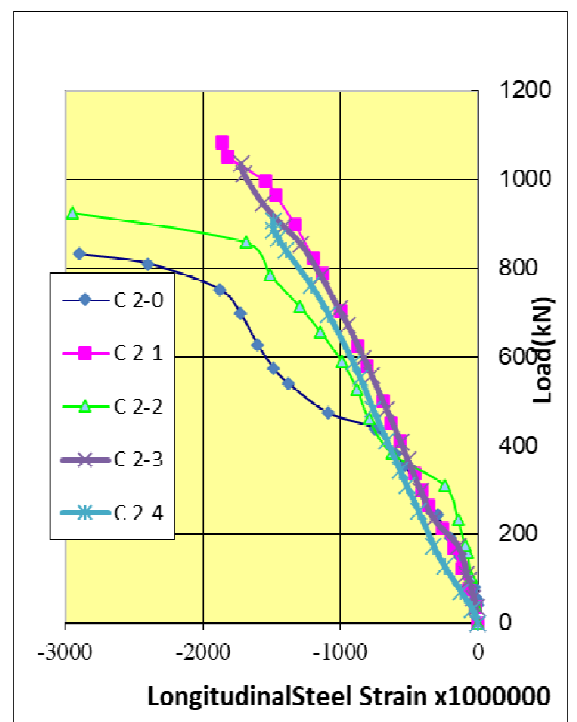

Fig. 13: Load-Steel Strain Curves for Group (2)

\subsection{Discussion of Results}

The experimental results showed the efficiency of the partial confinement of the specimen. The increase in column capacities ranged from $12 \%$ to $25 \%$ in Group (1), and from $13 \%$ to $32 \%$ in Group (2). It was observed that the specimen with partial dowel penetration showed higher increase in column capacities than specimen with full dowel penetration.

Moreover, specimen with 6 fully penetrated strips showed better behavior and higher capacity increase than specimen with 8 fully penetrated strips. This phenomenon is caused by the complete separation between the confined and the unconfined areas in the column cross section formed by the dowels. The higher the number of fully penetrated dowels is, the weaker the column becomes. The strains of the outer stirrups remained almost linear up to failure in the tested specimen and all specimen suffered a compression failure in concrete, keeping the natural failure mode of columns, in spite of the capacity increase. 

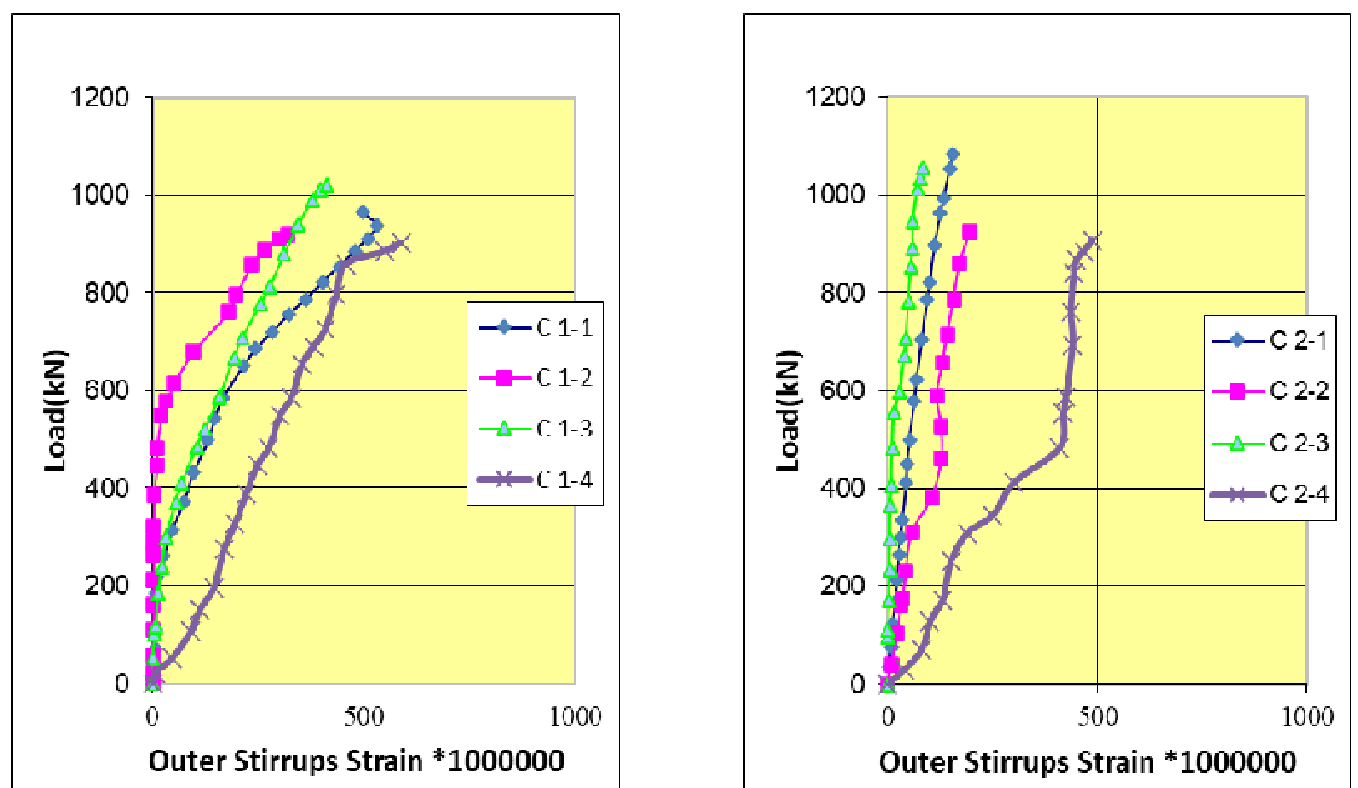

Fig. 14: Load-Out Stir. Strain Curves for Group (1) Fig. 15: Load- Out Stir. Strain Curves for Group (2)

\section{ANALYTICAL MODELS}

The specimens were modeled using finite element analysis. The used software was ABAQUS 6.12. The analysis was based on the non-linear iterative secant stiffness formulation. For compressive and tensile behavior, Concrete Damaged Plasticity model was used to describe the yield criterion of concrete. The stress strain curve of reinforcement was plotted as bilinear behavior. Cohesive Behavior model was used to describe the contact between concrete and outer stirrups (steel strips) with specified stiffness coefficients.

The deformed shapes of the Columns C 1-0, C 1-1 and C1-3 are shown in Figures 16,17 and 18 respectively.

The experimental and theoretical failure loads are compared in Table 3. The failure was considered in the theoretical results when the stress in concrete began to decrease after that the strain in concrete began to reach 0.003 . The difference between experimental and theoretical results was less than $6 \%$.

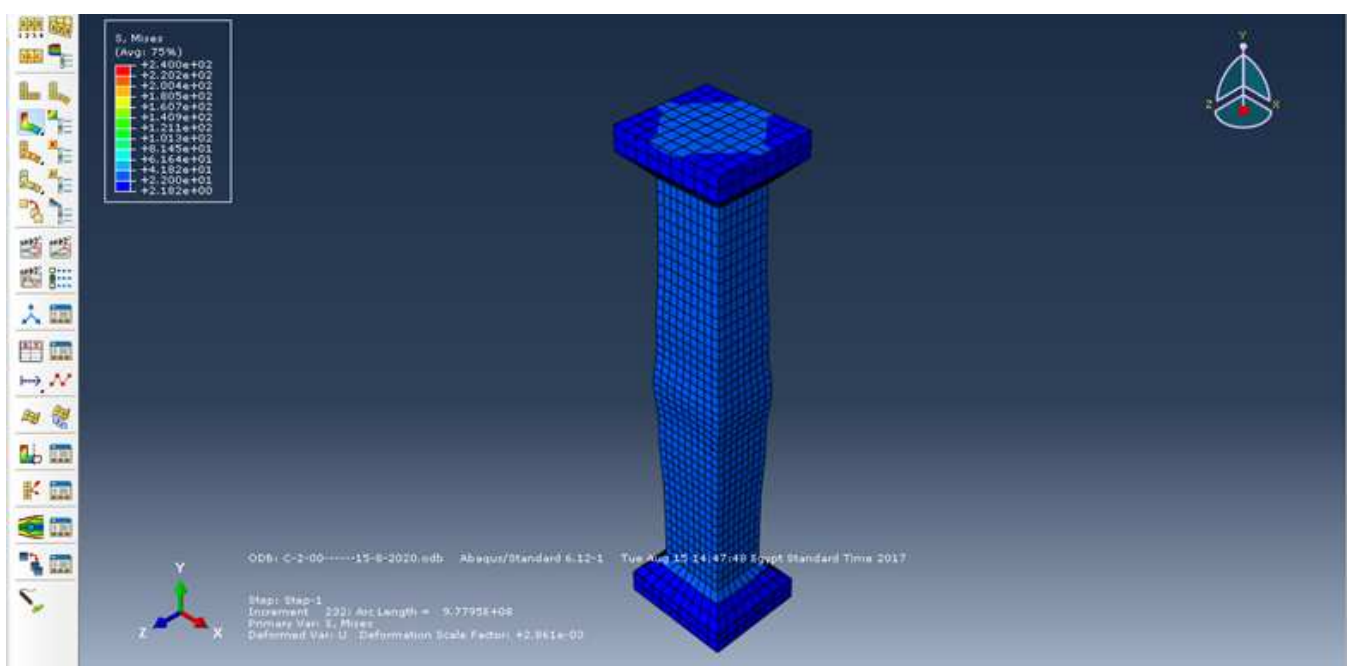

Fig. 16: Deformed Shape of Column C1-0 


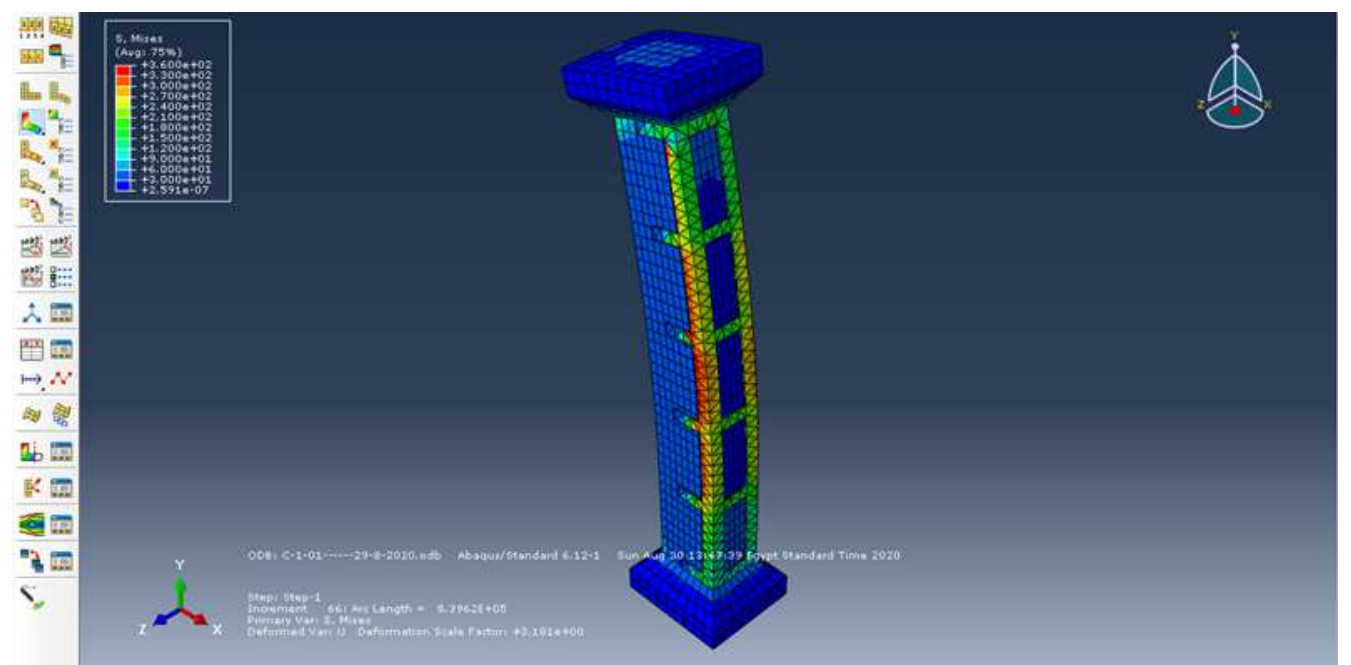

Fig. 17: Deformed Shape of Column C1-1

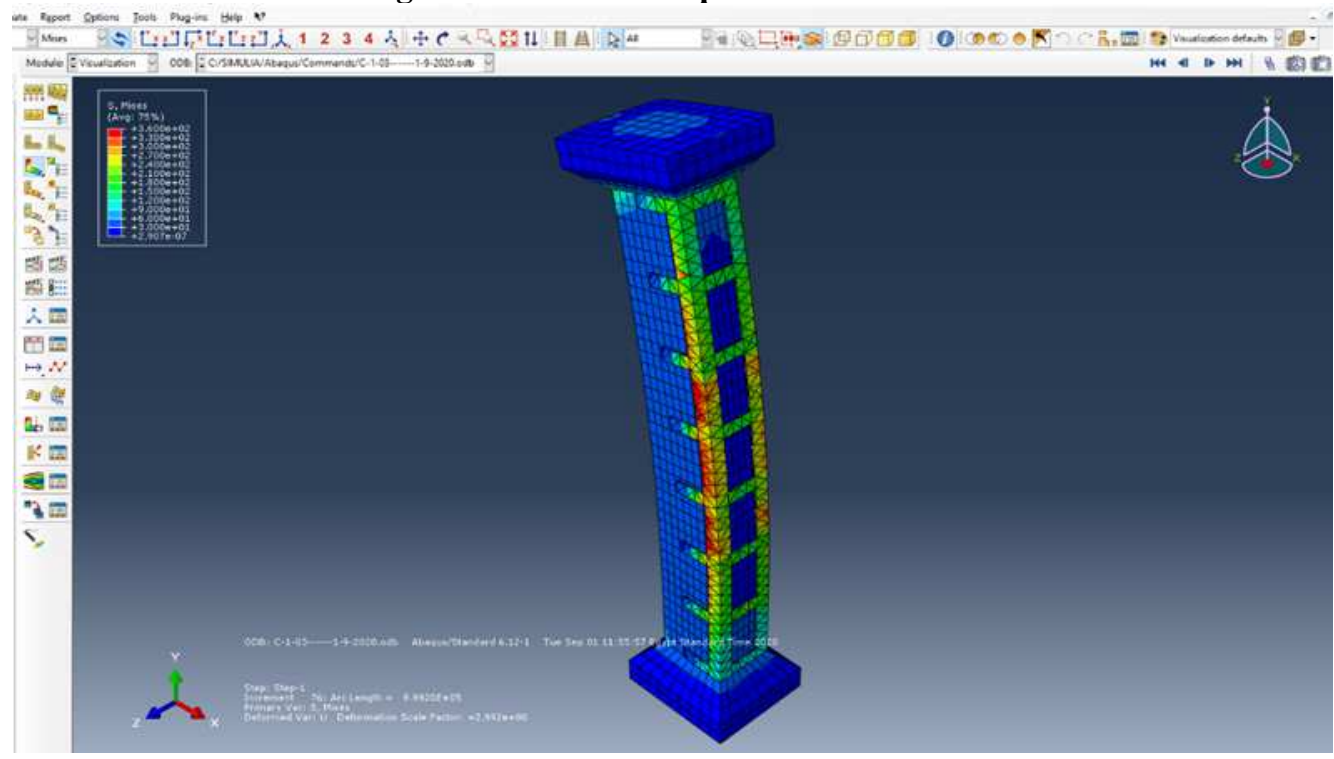

Fig. 18: Deformed Shape of Column C1-3

Table 3: Comparison between Experimental and Theoretical Results

\begin{tabular}{ccc}
\hline Specimens & $\begin{array}{c}\text { Experimental Failure } \\
\text { Loads }(\mathrm{kN})\end{array}$ & $\begin{array}{c}\text { Theoretical Failure } \\
\text { Loads }(\mathrm{kN})\end{array}$ \\
\hline C $1-0$ & 822 & 810 \\
C $1-1$ & 963 & 914 \\
C $1-2$ & 919 & 901 \\
C $1-3$ & 1012 & 980 \\
C $1-4$ & 901 & 850 \\
C 2-0 & 830 & 850 \\
C 2-1 & 1082 & 1110 \\
C 2-2 & 925 & 940 \\
C 2-3 & 1063 & 1150 \\
C 2-4 & 906 & 960 \\
\hline
\end{tabular}




\section{SUMMARY AND CONCLUSIONS}

The present study investigated the effect of the partial confinement of concrete columns using external stirrups with partial and full dowel penetration. This method should be useful in confining external columns in existing buildings, where it is difficult to confine the whole column perimeter. The following summarizes the findings of this investigation:

1. A successful method for confining exterior concrete columns partially to increase their capacities is introduced.

2. Partial confinement with fully penetrated dowels showed an increase of about $12 \%$ in column capacity, while specimen with partially penetrated dowels showed an increase of more than $25 \%$ in column capacity.

3. Full penetration of dowels forms a weak point in the column cross section by totally separating the confined and unconfined zones.

4. The column capacities can be closely predicted using Mander model.

5. Finite element models showed good agreement with the experimental results in the capacities and strain result. The difference between the experimental and theoretical results ranged between $2 \%$ to $6 \%$.

6. Based on the results of this study a full parametric study could be performed to pretend solid equations for the partial confinement.

\section{REFERENCES}

1. American Concrete Institue. (2008). ACI Committee 318: Building Code Requirements for Reinforced Concrete (ACI 318-2008) and Commentary (ACI 318R2008), American Concrete Institute.

2. Atia, E., Alkersh, M., Hilal, A., Razek, M.A. (2018). Confinement of Reinforced Concrete Columns Using Shape Memory Alloy Plates. International Journal of Scientific and Engineering Research (IJSER), 9(10), 824-828.

3. Hilal, A., Abdelrazik, M., Atia, E. (2016). Experimental and Analytical Study of Reinforced Concrete Columns Confined By Active and Passive External Stirrups. AlAzhar University Civil Engineering Research Magazine (CERM), 38 (2), 50-61.

4. Mander, J.B., Priestley, M.J.N., and Park, R., (1988). Theoretical Stress-Strain Model For Confined Concrete. Journal of Structural Engineering, 114(8), 1804-1826.

5. Matthys, S., Toutanji, H. and Gilbert, J. (2010). Behavior of Large-Scale Rectangular Columns Confined with FRP Composites. Journal of Composites for Construction ASCE, 14(1), 66-78.

6. Moghaddam, H., Samadi, M., Mohebbi, S. and Pilakoutas, K. (2010). Compressive Behavior of Concrete Actively Confined by Metal Strips, Part B: Analysis. Materials and Structures, 43, 1383-1396.

7. Park, R., and Paulay, T., (1975). Reinforced Concrete Structures. A WhilyInterscience Publication, Book, pp769. 